American University Washington College of Law

Digital Commons @ American University Washington College of

Law

Articles in Law Reviews \& Other Academic Journals

Scholarship \& Research

2008

From the Periphery to the Center? The Evolving WTO

Jurisprudence on Transparency and Good Governance

Padideh Ala'i

Follow this and additional works at: https://digitalcommons.wcl.american.edu/facsch_lawrev

Part of the International Trade Law Commons, and the Jurisprudence Commons 


\title{
FROM THE PERIPHERY TO THE CENTER? THE EVOLVING WTO JURISPRUDENCE ON TRANSPARENCY AND GOOD GOVERNANCE
}

\author{
Padideh Ala' $i^{\star}$
}

\section{ABSTRACT}

The rise of the regulatory state in the latter half of the 20th century is reflected in the text of the World Trade Organization (WTO) Agreements and specifically its transparency related obligations. The oldest transparency and good governance obligation of the WTO is Article X of General Agreement on Tariffs and Trade (GATT). Article X imposes broad publication and due process requirements on the administration of measures in the area of trade in goods. The language of Article $\mathrm{X}$ is duplicated or incorporated by reference throughout the WTO Agreements. During the GATT years (1947-94), Article X was a silent provision dismissed by GATT panels as 'subsidiary' to the other 'substantive' provisions of the GATT. Since the creation of the WTO, Article X has emerged from obscurity, and is now viewed as creating obligations of 'fundamental importance,' such as transparency and due process. In addition, there has been an exponential increase in the number of cases asserting Article X claims before WTO panels and the Appellate Body. The resulting treatment of such claims by the WTO dispute settlement bodies reflects both the emerging role of the WTO as a supranational administrative body and the continuing discomfort of panels and the Appellate Body with applying good governance obligations.

\section{INTRODUCTION}

This paper traces the jurisprudence of Article X of the General Agreement on Tariffs and Trade (GATT) of $1994 .{ }^{1}$ Article $\mathrm{X}$ is significant because it 'goes to the heart of a country's legal infrastructure, and more precisely to the nature and enforcement of its administrative law regime.'2 Article X was

* Professor of Law, Washington College of Law, American University, Washington, DC. E-mail: palai@wcl.american.edu. I would like to thank Lana Nigro and Lisa Schopler for their assistance with this article. An earlier version of this article was delivered at the fourth Global Administrative Law (GAL) Conference in Viterbo, Italy in June 2008.

${ }^{1}$ WTO, The Results of the Uruguay Round of Multilateral Trade Negotiations, the Legal Texts (Geneva 2003) 17.

2 Sylvia Ostry, 'China and the WTO: The Transparency Issue', 3 UCLA Journal of International Law and Foreign Affairs 1 (1998), at 2. 
proposed by the United States in 1947, and was influenced by the contemporaneous enactment of the US Administrative Procedures Act (APA). ${ }^{3}$ Article $\mathrm{X}$ requires that trade related measures be promptly published, administered in a uniform, impartial and reasonable manner and provide for independent review of administrative action that relates to customs matters.

During the GATT 1947 years, ${ }^{4}$ Article X was a silent provision dismissed by panels as 'subsidiary' to other 'substantive' GATT provisions. Since the creation of the World Trade Organization (WTO), Article X has emerged from obscurity, and has developed into a provision of fundamental importance as the embodiment of the principles of transparency and due process. ${ }^{5}$ The relative prominence of Article $\mathrm{X}$ in trade disputes in the WTO is a manifestation of the emerging role of the WTO as a global (supranational) regulatory body. ${ }^{6}$ The increased emphasis on Article $\mathrm{X}$ also highlights the potential role for the WTO in promoting 'good governance' norms in both the transnational and domestic context. ${ }^{7}$

This article will show that WTO Members are increasingly relying on good governance principles, such as transparency and due process in dispute settlement proceedings. These good governance principles, as embodied in Article $\mathrm{X}$, are most often invoked in connection with contentious trade issues, including the administration of anti-dumping or countervailing measures by the US Department of Commerce (DOC).

35 United States Code (USC) ss 551-559.

${ }^{4}$ WTO, above $\mathrm{n} 1$, at 423 .

${ }^{5}$ Transparency is generally defined as 'sharing information or acting in an open manner', or 'a measure of the degree of which information about official activity is made available to an interested party'. See William Mock, 'On the Centrality of Information Law: A Rational Choice Discussion of Information Law and Transparency', 17 John Marshall Journal of Computer and Information Law 1069, 1182 (1999).

${ }^{6}$ In the legal context, the focus of transparency is on procedural due process: publication, access to and flow of information, and independent judicial review. This article is not concerned with the internal governance of the WTO or the external transparency of the WTO as it relates to public (non-state) participation.

7 In this article 'governance' is defined as the 'process of decision-making and the process by which decisions are implemented'. See United Nations Economic and Social Commission for Asia and the Pacific (ESCAP), 'What is Good Governance?,' http://www.unescap.org/pdd/prs/ ProjectActivities/Ongoing/gg/governance.pdf (visited 16 May 2008). The term 'good governance' includes five basic characteristics: (1) participation, (2) transparency, (3) responsibility, (4) accountability, and (5) responsiveness; Commission on Human Rights, 'Role of Good Governance in the Promotion of Human Rights', U.N. Doc. E/CN.4/RES/2000/64 (April $27,2000)$. A strong argument can be made that the cumulative effect of the 'good governance' provisions of the WTO, for example requiring notification, publication, participation, responsiveness, and access to information, have potentially far greater impact on domestic governance of states than direct attempts at legal and institutional reform by the World Bank, the International Monetary Fund (IMF) and others. A prominent example of the influence of WTO's transparency and good governance provisions is seen in the case of China, where thousands of pieces of legislation were promulgated in connection with China's accession to the WTO. 
The growing centrality of Article X also reflects: (i) an emerging global consensus regarding good governance values such as transparency, access to information, and participation, which must inform both domestic and global administrative systems; (ii) the evolution of the GATT from a system based on tariffs, reciprocal bargaining and exchange of concessions to one concerned with rule-making; and (iii) an attempt by the dispute settlement system to accommodate the emerging role of the WTO as a rulemaking body by enforcing its good governance mandate in a manner that avoids political controversy and charges of overreaching by the Members. For example, as discussed below, a panel may expansively interpret a provision of Article $\mathrm{X}$, but then either refuse to address the Article $\mathrm{X}$ claim in the name of judicial economy or find that the measure in question does not in fact violate Article $\mathrm{X}$ requirements of transparency or due process. ${ }^{8}$

This article will first define terms and explore the roots and scope of Article $\mathrm{X}$ of GATT 1994. It will then discuss the application of Article X during the GATT 1947 years (1947-94) when, after being a dormant provision for almost forty years, it was dismissed in the 1980s and early 1990s as merely subsidiary to the more 'substantive' obligations contained in GATT 1947. It will then explore the impact of WTO jurisprudence on the scope and application of Article X's requirements of transparency and due process by analyzing the interpretations and applications of Article X by the WTO panels and the Appellate Body from 1995 to the present. This article will then review the most prominent Article X cases brought under the Understanding on Rules and Procedures Governing the Settlement of Disputes (DSU), ${ }^{9}$ culminating with European Communities - Selected Customs Matters (EC - Selected Customs Matters), in which all of the claims were based on alleged violations of Article X. ${ }^{10}$ Finally, this article will make some observations about the future of Article X under the Dispute Settlement Mechanism (DSM) and its implications for the overall goal and mandate of the WTO.

\section{HISTORY OF ARTICLE X OF GATT 1994}

Article X was initially proposed by the United States as Article 15 of the draft Charter of the International Trade Organization (ITO), ${ }^{11}$ which was subsequently adopted by the GATT 1947 Contracting Parties. At the time of its adoption, no other country expressed an interest in Article $\mathrm{X}$, and it was

${ }^{8}$ In such cases, the panels' extensive discussion of Art. X provisions may nevertheless set the stage for the future where international review of domestic administrative regimes may be less politically controversial. See below, Part VII.

9 WTO, above n 1 , at 354 .

${ }^{10}$ WTO Appellate Body Report, European Communities - Selected Customs Matters (EC - Selected Customs Matters), WT/DS315/AB/R, Adopted on 11 December 2006; WTO Panel Report, European Communities - Selected Customs Matters, WT/DS315/R, Adopted on 11 December 2006.

${ }^{11}$ Ostry, above n 2, at 3. 
adopted without any discussion or amendment. The proposed text of Article X generally followed the text of the APA, which was enacted in $1946 .{ }^{12}$ At the time of its adoption, the Contracting Parties viewed Article $\mathrm{X}$ as creating no new obligations. ${ }^{13}$ The text of Article X of GATT 1947 (which remains unchanged under GATT 1994), states:

(1) Laws, regulations, judicial decisions and administrative rulings of general application ... pertaining to the classification or the valuation of products for customs purposes, or to rates of duty, taxes or other charges, or to requirements, restrictions or prohibitions on imports or exports, or on the transfer or payments therefore, or affecting their sale, distribution, transportation... or other use shall be published promptly in such manner as to enable governments and traders to become acquainted with them. Agreements affecting international trade policy... shall also be published.

(2) No measure of general application... effecting an advance in a rate of duty ... or imposing a new or more burdensome requirement, restriction or prohibition on imports... shall be enforced before such measure has been officially published.

(3) (a) Each [Member] shall administer in a uniform, impartial and reasonable manner all its laws, regulations, decisions and rulings of the kind described in paragraph $1 \ldots$

(b) Each [Member] shall maintain, or institute as soon as practicable, judicial, arbitral or administrative tribunals or procedures for the purpose... of the prompt review and correction of administrative action relating to custom matters... Such tribunals or procedures shall be independent of the agencies entrusted with administrative enforcement... ${ }^{14}$

It has been argued that the United States' motivation for proposing Article $\mathrm{X}$ was to level the playing field for US traders who faced opaque and informal administrative structures in other countries, while US administrative processes had been made more transparent with the enactment of the APA. ${ }^{15}$ Article $\mathrm{X}$ may have been intended to assist US exporters in the post-World War II

12 Article X was also 'partially based on Articles 4 and 6 of the 1923 International Convention Relating to the Simplification of Customs Formalities'. See GATT, Analytical Index: Guide to GATT Law and Practice, (6th ed, WTO \& Bernan Press 1995) vol. I, at 309. See also Padideh Ala'i, 'The Multilateral Trading System and Transparency, in Trends', in Alan S. Alexandroff (ed), World Trade: Essays in Honor of Sylvia Ostry (Durham, NC: Carolina Academic Press 2007) 105-132 at 105, 108-112 (discussing the history and evolution of the US APA and its relationship to Art. X of GATT 1947).

${ }^{13}$ In fact, a senior Canadian negotiator is quoted as stating at the time of the original enactment of Art. X that it contained no additional substantive requirements and should therefore not be of any concern. Sylvia Ostry, 'Article X and the Concept of Transparency in the GATT/ WTO', in Alan S. Alexandroff, Sylvia Ostry and Rafael Gomez (eds), China and the Long March to Global Trade: The Accession of China to the World Trade Organization (UK: Routledge 2002) 123-24. See also Ostry, above n 2, at 4.

14 Article X of the GATT, above $\mathrm{n} 1$ (emphasis added).

15 See John H. Jackson, World Trade and the Law of GATT (Charlottesville, Virginia: The Michie Company 1969) 461-64. 
world, but its provisions may also be interpreted as expressing the values that led to the enactment of the APA, such as imposing limitations on the exercise of executive discretion through transparency and due process. ${ }^{16}$

From 1947-84 there was no mention of Article X in any adopted GATT panel decisions. ${ }^{17}$ By the mid-1980s, faced with diminished competitiveness, the United States became increasingly concerned about the proliferation of nontariff barriers (NTBs), including non-transparent and ad hoc administration of customs regulations. ${ }^{18}$ Early GATT 1947 cases involving Article X were filed by the United States against Japan's non-transparent administration of import quota systems and the extensive use of the informal system of 'administrative guidance' by Japan. ${ }^{19}$

\section{ARTICLE X AND THE GATT 1947}

Article X was mentioned in only nine adopted GATT 1947 panel decisions. ${ }^{20}$ The United States was involved in all of these cases: six as complainant, ${ }^{21}$

16 See Ala'i, above n 12, at 109-12 (noting that while the APA may have been an attempt to limit executive discretion it also led to the rise of the administrative state with the proliferation of agencies under the executive branch of government).

17 Prior to the formation of the WTO, the GATT dispute settlement panel was driven by consensus that required agreement of all parties for the formation or adoption of panel decisions. The result of this consensus-driven approach was few adopted decisions, and even fewer dealing with controversial issues that may have threatened the legitimacy of the system. This may have included avoiding Art. X transparency claims.

18 These issues were addressed more frequently through other mechanisms. For example, in 1977 the United States passed the Foreign Corrupt Practices Act, 15 USC $\S 78 \mathrm{~m}(\mathrm{~b})(2)(\mathrm{B})$.

19 See e.g. GATT Panel Report, Fapan - Trade in Semi-Conductors (Fapan - Semi-Conductors), L/6309, Adopted on 4 May 1988; GATT Panel Report, Fapan - Restrictions on Imports of Certain Agricultural Products (Fapan - Agricultural Products I), L/6253, Adopted on 2 March 1988; GATT Panel Report, Fapanese Measures on Imports of Leather (Fapan - LeatherII (US)), L/5623, Adopted on 15 May 1984.

20 GATT Panel Report, United States - Countervailing Duties on Non-Rubber Footwear from Brazil (US - Non-Rubber Footwear), SCM/94, Adopted on 13 June 1995; GATT Panel Report, Canada - Import, Distribution and Sale of Certain Alcoholic Drinks by Provincial Marketing Agencies (Canada - Provincial Liquor Boards (US)), DS17/R, Adopted on 18 February 1992; GATT Panel Report, European Economic Community - Regulation on Imports of Parts and Components (EEC - Parts and Components), L/6657, Adopted on 16 May 1990; GATT Panel Report, Canada - Import Restrictions on Ice Cream and Yoghurt (Canada - Ice Cream and Yoghurt), L/6568, Adopted on 5 December 1989; GATT Panel Report, European Economic Community - Restrictions on Imports of Apples - Complaint by the United States (EEC - Apples (US)), L/6513, Adopted on 22 June 1989; GATT Panel Report, European Economic Community - Restrictions on Imports of Dessert Apples - Complaint by Chile (EEC - Dessert Apples), L/6491, Adopted on 22 June 1989; GATT Panel Report, Republic of Korea Restrictions on Imports of Beef - Complaint by the United States (Korea - Beef(US)), L/6503, Adopted on 7 November 1989; GATT Panel Report, fapan - Semi-Conductors, above n 19; GATT Panel Report, Fapan - Agricultural Products I, above n 19; GATT Panel Report, Fapan - Leather II (US), above n 19.

21 Out of the seven cases initiated by the United States three were against Japan. See GATT Panel Report, Fapan - Semi-Conductors, above n 19; GATT Panel Report, Fapan-Agricultural Products I, above n 19; GATT Panel Report, Fapan - Leather II (US), above n 19. Two were against Canada. See GATT Panel Report, Canada - Provincial Liquor Boards (US), ibid; 
one as respondent; ${ }^{22}$ and two as interested third party. ${ }^{23} \mathrm{~A}$ review of these reports shows that, although the United States and other Contracting Parties to the GATT 1947 recognized that the administration of a measure could give rise to a claim, they preferred to address a measure as being inconsistent with more 'substantive' provisions, such as Article XI:1 of the GATT $1947 .^{24}$ Article XI:1 of the GATT 1947 prohibits quotas, import or export licenses, or any other measure that in any manner restricts trade. The term 'other measure' can be interpreted broadly to cover a seemingly endless list of NTBs, including inter alia import licensing requirements, anti-dumping measures, and health and safety regulation. The breadth of the Article XI:1 obligation allowed GATT panels to find any measure inconsistent with the GATT 1947 without having to refer to the 'administrative' or 'subordinate' claim of Article X.

Three of the nine adopted GATT 1947 cases involving Article X were brought by either the United States or the European Community (EC) [formerly the European Economic Community (EEC)] against Japan. ${ }^{25} \mathrm{At}$ issue in those three cases was the level of transparency required under Article X. ${ }^{26}$ In Fapanese Measures on Imports of Leather (Fapan - Leather II (US)), the United States challenged the administration of the Japanese quota system on imported leather. ${ }^{27}$ The United States argued that the Japanese import leather quota system violated Articles X:1 and X:3 of the GATT 1947 because Japan had failed to publish the total import quotas and certain administrative rulings related to it. ${ }^{28}$ Of particular concern was the fact that in administering

GATT Panel Report, Canada - Ice Cream and Yoghurt, ibid. One was against Korea: GATT Panel Report, Korea - Beef (US), ibid.

22 See GATT Panel Report, US - Non-Rubber Footwear, above n 20.

${ }^{23}$ Although not an official third party, the measure at issue was related to US actions forcing Japan to limit its exports to the European market. See GATT Panel Report, Fapan - SemiConductors, above n 19, para 4 (acknowledging the special nature of the matter and providing for an adequate opportunity for the United States to participate). See also GATT Panel Report, EEC - Parts and Components, above n 20.

${ }^{24}$ Article XI:1 of the GATT 1947 states: 'No prohibitions or restrictions other than duties, taxes or other charges, whether made effective through quotas, import or export licenses or other measures, shall be instituted or maintained by any contracting party on the importation of any product of the territory of any other contracting party or on the exportation or sale for export of any product destined for the territory of any other contracting party.' See WTO, above $\mathrm{n} 1$.

${ }^{25}$ See GATT Panel Report, fapan - Semi-Conductors, above n 19; GATT Panel Report, fapan Agricultural Products I, above n 19; GATT Panel Report, fapan - Leather II (US), above n 19.

${ }^{26}$ See GATT Panel Report, Fapan - Agricultural Products I, ibid, para 5.4.1.4 (finding that the practice of 'administrative guidance' is 'a traditional tool of Japanese Government policy based on consensus and peer pressure' and thus finding that under the special circumstances in Japan such administrative guidance could be considered a governmental measure). See also GATT Panel Report, Fapan - Semi-Conductors, above n 19, para 107 (clarifying the panel's analysis of 'administrative guidance' as a governmental measure in fapan - Agricultural Products I).

${ }^{27}$ GATT Panel Report, fapan - Leather II (US), above n 19.

${ }^{28}$ Ibid, para 16. 
the leather quotas, Japan had allocated licenses so as to channel import trade through Japanese producers and distributors. The United States argued that Japanese producers had 'no incentive to fully utilize the quota amounts allocated to them. ${ }^{29}$ The panel ruled that the Japanese quota system was in violation of Article XI:1, and it did not need to address the Article $\mathrm{X}$ issue. ${ }^{30}$

The second case involving Article X, Fapan - Restrictions on Imports of Certain Agricultural Products (Fapan - Agricultural Products I), was decided in 1988. In that dispute, the United States argued that the Japanese quota system for certain agricultural products, in addition to violating Article XI:1, also violated Articles X:1 and X:3. The United States alleged that, in administering the agricultural quota system, Japan had failed to 'publish adequate and timely information on quota volume or value' contrary to Article $\mathrm{X}: 1$, which constituted an unreasonable administration of the import quota system in violation of Article X:3 (a). ${ }^{31}$ Japan responded that there was no requirement to publish information beyond the total amount of the quota to be issued and criteria for application. Japan further argued that any additional disclosure of information as to the identity of the quota holders and other related information was not acceptable as it would only 'cause unnecessary confusion' and induce 'anti-competitive intervention among importers. ${ }^{32}$ The panel found Japan's import quota restrictions inconsistent with Article XI:1, and declined to rule on the Article X claims. $^{33}$

Finally, in Fapan - Trade in Semi-Conductors (Fapan-Semi-Conductors), ${ }^{34}$ the EC invoked Article X in connection with the Third Country Monitoring System (Monitoring System) that was created by Japan pursuant to a voluntary export restraint arrangement with the United States. At issue was the use of 'administrative guidance' by Japan in implementing the Monitoring System that recorded both the cost and sale prices of semi-conductors that were exported to Europe and 'encouraged' Japanese exporters not to dump in the European market. ${ }^{35}$ Although the panel decided that the case did not warrant a decision on the Article X claim, it did recognize the important role 'administrative guidance' played in the promotion and enforcement of governmental policy in

29 Ibid, para 28.

${ }^{30}$ Ibid, paras 44, 57.

31 GATT Panel Report, fapan - Agricultural Products I, above n 19, para 3.1.1. The United States also argued that Japan had failed to meet the requirements of Arts X:1 and 3 'in terms of transparency, specificity and timing of notice given'. (para 3.5.1).

32 Ibid, para 3.5.2.

33 Ibid, paras 5.4 .2 and 6.2 .

34 See GATT Panel Report, Fapan - Semi-Conductors, above n 19.

35 Ibid, para 35 (outlining the EC argument that Japan's administrative guidance controlled export prices, export volume, production volume and other aspects related to exports. It was also stated in Japan's Position Paper that 'Japan exercised administrative guidance to achieve production cutbacks'). 
Japan. ${ }^{36}$ The panel, citing fapan - Agricultural Products I, stated that 'the practice of administrative guidance ... was a traditional tool of Japanese government policy based on consensus and peer pressure, ${ }^{37}$ implying that the workings of Japan's system of administrative guidance was not meant to be transparent.

Detailed discussion of Article X appears in only two GATT 1947 panel decisions. First, in Canada - Import, Distribution and Sale of Certain Alcoholic Drinks by Provincial Marketing Agencies (Canada - Provincial Liquor Boards (US)), ${ }^{38}$ the panel concluded that Article $\mathrm{X}$ did not require Canadian provinces to provide 'information affecting trade available to domestic and foreign suppliers at the same time, nor did it require Contracting Parties, to publish trade regulations in advance of their entry into force. ${ }^{39}$ Second, in European Economic Community - Restrictions on Imports of Dessert Apples Complaint by Chile (EEC - Dessert Apples), ${ }^{40}$ the panel ruled that the specific act of back-dating quotas on imports of dessert apples by the EEC was inconsistent with the publication requirement of Article $\mathrm{X}$. This is the only adopted GATT 1947 decision to find a violation of Article X. However, the panel also held that the EC's administration of its quota system was not in violation of the 'uniformity' requirement of Article $\mathrm{X}: 3(\mathrm{a})$. The panel concluded that the requirement of 'uniformity' in administration imposed by Article X:3(a) did not require EC Members to have identical administrative procedures with regards to the import of dessert apples. In reaching its conclusion, the panel emphasized the substantive provisions of the GATT 1947 by first finding violations of Article XI:1 and Article XIII of GATT 1947 and then only finding a violation of Article X with regards to the specific act of back-dating import restrictions from the date of publication to have been a violation of Article X:1. 1947. ${ }^{41}$

In the remaining GATT 1947 cases, panels merely dismissed the Article X claims as subsidiary issues that did not need to be addressed. ${ }^{42}$ The last adopted GATT 1947 case involving an Article X claim was United States Countervailing Duties on Non-Rubber Footwear from Brazil (US - Non-Rubber Footwear). ${ }^{43}$ The panel dismissed the Article X:3(a) claim as not being within the terms of reference of the panel. ${ }^{44}$ Interestingly, this case does

\footnotetext{
${ }^{36}$ Ibid, paras 35, 53, and 128. In that case, the Monitoring System had already been found to be inconsistent with Art. XI:1 of the GATT 1947.

37 Ibid, para 107.

38 GATT Panel Report, Canada - Provincial Liquor Boards (US), above n 20.

39 Ibid, para 5.34 (emphasis added).

40 GATT Panel Report, EEC - Dessert Apples, above n 20.

${ }^{41}$ Ibid, paras 12.29-30, (finding that minimal administrative differences by themselves could not constitute a violation of Art. X:3 and that the administration of the quotas was a violation of Art. XIII).

42 See GATT Panel Report, Canada - Ice Cream and Yoghurt, above n 20; GATT Panel Report, Korea - Beef (US), above n 20.

43 GATT Panel Report, US - Non-Rubber Footwear, above n 20.

${ }^{44}$ Ibid, para 6.2 .
} 
foreshadow a line of cases discussed below where administration of trade remedies by the United States DOC is challenged as being inconsistent, among other things, with the requirements of Article $\mathrm{X}: 3(\mathrm{a})$.

\section{THE EXPANSION OF THE WTO TRADE MANDATE AND ITS IMPACT ON ARTICLE X}

Upon creation of the WTO, Article X of GATT 1947 became Article X of GATT 1994 and was included as part of Annex 1A of the WTO Agreement without any amendment. ${ }^{45}$ Annex $1 \mathrm{~A}$ also includes other trade agreements that had been negotiated under the auspices of the GATT 1947 on trade in goods. ${ }^{46}$ Article $\mathrm{X}$ is specifically mentioned in the following Annex 1A agreements: Agreement on Implementation of Article VII of the GATT 1994 (Customs Valuation Agreement), ${ }^{47}$ Agreement on Rules of Origin, ${ }^{48}$ and Agreement on Safeguards. ${ }^{49}$ The other Annex 1A agreements do not mention Article $\mathrm{X}$, but do contain provisions addressing transparency and due process in the administration of measures, including the Agreement on the Application of Sanitary and Phytosanitary Measures (SPS Agreement); ${ }^{50}$ Agreement on Technical Barriers to Trade (TBT Agreement); ${ }^{51}$ Agreement on the Implementation of Article VI of the GATT 1994 (Antidumping Agreement); ${ }^{52}$ Agreement on Subsidies and Countervailing Measures (SCM Agreement); ${ }^{53}$ and the Agreement on Import Licensing Procedures (Licensing Agreement). ${ }^{54}$ Outside of trade in goods, the requirements of Article $\mathrm{X}$ are replicated throughout the Agreement on Trade in Services $(\text { GATS })^{55}$ and the Agreement on Trade Related Aspects of Intellectual

45 Paragraph 1 of the GATT 1994.

46 Under the GATT 1947, Contracting Parties could pick and choose which agreements they wanted to sign and ratify while still maintaining their membership in the GATT. This changed with the creation of the WTO, where Members are required to sign all of the relevant WTO agreements. The Covered Agreements are the Agreements on Agriculture, Sanitary and Phytosanitary Measures, Textiles and Clothing, Technical Barriers to Trade, Trade-Related Investment Measures, Anti-Dumping, Custom Valuation, Pre-shipment Inspection, Rules of Origin, Import Licensing Agreement, Subsidies and Countervailing Measures, and Safeguards.

47 WTO, above n 1 , at 172 .

48 Ibid, at 211.

49 Ibid, at 275.

50 Ibid, at 59.

51 Ibid, at 21 .

52 Ibid, at 147.

53 Ibid, at 231.

54 Ibid, at 223.

55 Ibid, at 284. [Specifically, Art. III of the GATS (Transparency) largely follows the language of Art. X of the GATT 1994 and requires publication of all relevant measures including international agreements affecting trade in services. In addition, Art. III of the GATS requires that WTO members annually inform the WTO Council for Trade in Services of any changes made to the laws that affect trade in services and the commitments that each member has made on that agreement. It also requires all members to 'establish one or more enquiry point to provide specific information to other members'. Article VI of the GATS requires members to maintain 'judicial, arbitral or administrative tribunals' to review administrative decisions affecting trade in services.] 
Property (TRIPS). ${ }^{56}$ In addition, the Trade Policy Review Mechanism (TPRM) monitors 'domestic transparency in government decision-making in the trade policy-making area. ${ }^{57}$ In view of the fact that Article $\mathrm{X}$ of GATT is only applicable to trade in goods, this article will not discuss in detail the scope of the transparency provisions of GATS, TRIPS or the TPRM.

The relationship between the transparency and due process obligations of Article X of GATT 1994 and the provisions of the other Annex 1A agreements is far from clear. ${ }^{58}$ The General Interpretative Note to Annex 1A (Interpretative Note) states:

In the event of conflict between a provision of [GATT] 1994 and a provision of another agreement in Annex 1A to the Agreement Establishing the [WTO], the provision of the other agreement shall prevail to the extent of the conflict. ${ }^{59}$

There is no agreement on the interpretation of the term 'conflict' except in cases where provisions directly contradict one another. Such a direct substantive conflict is unlikely to arise in the context of Article $\mathrm{X}$ as it is concerned with transparency and due process in the administration of a measure. This absence of clarity begs a number of questions: What is the relationship between Article $\mathrm{X}$ and the provisions of other Annex $1 \mathrm{~A}$ agreements? When a measure falls within the scope of an Annex 1A agreement is it still subject to the transparency and due process requirements of Article X? Are Article X obligations independent of the due process requirements of the other Annex 1A agreements? How should the term 'to the extent of the conflict' as stated in the Interpretative Note be construed in relation to Article X?

As the discussion below will show, WTO panels and the Appellate Body have held that the Interpretative Note does not prohibit concurrent application of Article X of GATT 1994 and provisions of other Annex 1A agreements. But, as a general rule, panels and the Appellate Body have tended to

${ }^{56}$ Ibid, at 321 [Art. 63 of the TRIPS (Transparency) requires publication of all intellectual property related measures and notification to the WTO Council for TRIPS. In addition, Art. 63.3 allows Members to object to another Member's specific judicial and administrative rulings in the area of intellectual property and to request detailed written justification for the ruling].

${ }^{57}$ Ibid, at 308. Part B of the TPRM states:

Domestic Transparency-Members recognize the inherent value of domestic Transparency of government decision-making on trade policy matters for both Members' economies and the multilateral trading system, and agree to encourage and promote greater transparency within their own systems, acknowledging that the implementation of domestic transparency must be on a voluntary basis and take account of each Member's legal and political systems.

${ }^{58}$ This is important not only within the context of Art. X, but also the other 'substantive' provisions of GATT 1994, including: Arts. I (most-favored-nation), II (tariff commitments), III (non-discriminatory application of internal measure), and Art. XI:1 (prohibition on quotas and NTBs).

59 WTO, above $\mathrm{n} 1$, at 16 . 
focus on more specific provisions of the other Annex 1A agreements. This focus on the relevant provisions of Annex 1A agreements (as opposed to GATT 1994) has not resulted in complete marginalization of Article X requirements of transparency and due process.

\section{INTERPRETATION OF ARTICLE X GATT 1994: EMERGING FROM OBSCURITY}

Since the founding of the WTO, there have been at least twenty cases involving consideration of Article X of the GATT 1994, ${ }^{60}$ and almost half of

${ }^{60}$ WTO Appellate Body Report, EC - Selected Customs Matters, above n 10; Panel Report, EC Selected Customs Matters, above n 10; WTO Appellate Body Report, WTO Panel Report, United States - Measures Relating to Shrimp from Thailand, WT/DS343/R, circulated 29 February 2008; WTO Panel Report, United States - Customs Bond Directive for Merchandise Subject to AntiDumping/Countervailing Duties (US - Customs Bond Directive), WT/DS345/R, circulated 29 February 2008; WTO Appellate Body Report, United States - Customs Bond Directive for Merchandise Subject to Anti-Dumping/Countervailing Duties (US - Customs Bond Directive), WT/ DS345/AB/R, circulated 16 July 2008; WTO Panel Report, Turkey - Measures Affecting the Importation of Rice, WT/DS334/R, Adopted on 21 September 21 2007; Mexico - Tax Measures on Soft Drinks and Other Beverages (Mexico - Taxes on Soft Drinks), WT/DS308/AB/R, Adopted on 24 March 2006); WTO Panel Report, Mexico - Tax Measures on Soft Drinks and Other Beverages (Mexico - Taxes on Soft Drinks), WT/DS308/R, Adopted on 24 March 2006; WTO Appellate Body Report, Dominican Republic - Measures Affecting the Importation and Internal Sale of Cigarettes (Dominican Republic - Import and Sale of Cigarettes), WT/DS302/AB/R, Adopted on 19 May 2005; WTO Panel Report, Dominican Republic - Measures Affecting the Importation and Internal Sale of Cigarettes (Dominican Republic - Import and Sale of Cigarettes), WT/DS302/R, Adopted on 19 May 2005; WTO Appellate Body Report, United States - Sunset Reviews of Anti-Dumping Measures on Oil Country Tubular Goods from Argentina (US - Oil Country Tubular Goods Sunset Reviews), WT/ DS268/AB/R, Adopted on 17 December 2004; WTO Panel Report, United States - Sunset Reviews of Anti-Dumping Measures on Oil Country Tubular Goods from Argentina (US - Oil Country Tubular Goods Sunset Reviews), WT/DS268/R, Adopted on 17 December 2004; WTO Appellate Body Report, United States - Continued Dumping and Subsidy Offset Act of 2000, WT/DS234/AB/R, Adopted on 27 January 2003; WTO Panel Report, United States - Continued Dumping and Subsidy Offset Act of 2000, WT/DS234/R, Adopted on 27 January 2003; WTO Panel Report, Egypt-Definitive Anti-Dumping Measures on Steel Rebar from Turkey, WT/DS211/R, Adopted on 1 October 2002; WTO Appellate Body Report, United States - Anti-Dumping Measures on Certain Hot-Rolled Steel Products from Fapan (US - Hot-Rolled Steel), WT/DS184/AB/R, Adopted on 23 August 2001; WTO Panel Report, United States - Anti-Dumping Measures on Certain Hot-Rolled Steel Products from Fapan (US - Hot-Rolled Steel), WT/DS184/R, Adopted on 23 August 2001; WTO Panel Report, United States - Anti-Dumping Measures on Stainless Steel Plate in Coils and Stainless Steel Sheet and Strip from Korea (US - Stainless Steel), WT/DS179/R, Adopted on 1 February 2001; WTO Panel Report, Argentina - Measures Affecting the Export of Bovine Hides and the Import of Finished Leather (Argentina - Hides and Leather), WT/DS155/R, Adopted on 16 February 2001; WTO Panel Report, United States - Anti-Dumping Duty on Dynamic Random Access Memory Semiconductors (DRAMS) of One Megabit or Above from Korea (US - DRAMS), WT/DS99/R, Adopted on 19 March 1999; WTO Appellate Body Report, fapan - Measures Affecting Agricultural Products, WT/DS76/AB/R, Adopted on 19 March 1999; WTO Panel Report, Fapan - Measures Affecting Agricultural Products, WT/DS76/R, Adopted on 19 March 1999; WTO Appellate Body Report, United States - Import Prohibition of Certain Shrimp and Shrimp Products (US - Shrimp), WT/DS58AB/R, Adopted on 6 November 1998; WTO Panel Report, United States - Import Prohibition of Certain Shrimp and Shrimp Products (US - Shrimp), WT/DS58/R, Adopted on 6 November 1998; WTO Appellate Body Report, European Communities - Measures Affecting Importation of Certain Poultry Products (EC - Poultry), WT/ 
these cases have been brought against the United States and have concerned the administration of safeguard, anti-dumping and countervailing duty laws. A wide variety of countries at differing levels of economic development have invoked Article X including: Argentina, Australia, Brazil, Chile, Costa Rica, Ecuador, Guatemala, Honduras, India, Indonesia, Korea, Mexico, Thailand, Turkey, and the United States. In contrast to the GATT 1947 days, no WTO Member has referred to their Article X claim as a 'subsidiary' claim.

Some Article X claims brought before WTO panels and the Appellate Body have continued the GATT 1947-era practice of deferring a discussion of the provision in favor of other GATT 1994 violations. However, even in such cases, panels and the Appellate Body have refrained from stating that an Article X claim is a subsidiary issue. As the discussion below will show, even in cases where the panels or the Appellate Body have not found a violation of Article $\mathrm{X}$, they have underscored the importance of Article X obligations and engaged in extensive discussions of the scope and meaning of its provisions. In addition, unlike the GATT 1947 years, WTO panels and the Appellate Body have repeatedly found measures to be inconsistent with the provisions of Article X, including: Argentina - Measures Affecting the Export of Bovine Hides and the Import of Finished Leather (Argentina - Hides and Leather), ${ }^{61}$ Dominican Republic Measures Affecting the Importation and Internal Sale of Cigarettes (Dominican Republic - Import and Sales of Cigarettes), ${ }^{62}$ EC - Selected Customs Matters, ${ }^{63}$ and United States - Customs Bond Directive for Merchandise Subject to AntiDumping/Countervailing Duties (US - Customs Bond Directive). ${ }^{64}$

In the WTO era, Article X of GATT 1994 was first analyzed in 1997 by the Appellate Body in United States - Restrictions on Imports of

DS69/AB/R, Adopted on 23 July 1998; WTO Panel Report, European Communities - Measures Affecting Importation of Certain Poultry Products (EC - Poultry), WT/DS69/R, Adopted on 23 July 1998; WTO Panel Report, Indonesia - Certain Measures Affecting the Automobile Industry, WT/DS54/R, WT/DS55/R, WT/DS59/R, WT/DS64/R, Adopted on 23 July 1998; WTO Panel Report, Fapan - Measures Affecting Consumer Photographic Film and Paper (Fapan Film), WT/DS44/R, Adopted on 22 April 1998; WTO Panel Report, European Communities - Regime for the Importation, Sale and Distribution of Bananas (EC - Bananas III (Mexico)), WT/DS/27/R/MEX, 25 September 1997; WTO Appellate Body Report, European Communities - Regime for the Importation, Sale and Distribution of Bananas (EC - Bananas III), WT/DS/27/AB/R, Adopted on 25 September 1997; WTO Appellate Body Report, United States - Restrictions on Imports of Cotton and Man-Made Fibre Underwear (United States - Underwear), WT/DS24/AB/R, Adopted on 25 February 1997); WTO Panel Report, United States - Restrictions on Imports of Cotton and Man-Made Fibre Underwear (United States - Underwear), WT/DS24/R, Adopted on 25 February 1997.

${ }^{61}$ Panel Report, Argentina - Hides and Leather, ibid.

62 Appellate Body Report, Dominican Republic - Import and Sale of Cigarettes, above n 60.

${ }^{63}$ Appellate Body Report, EC - Selected Customs Matters, above n 10.

${ }^{64}$ Panel Report, US - Customs Bond Directive, above n 60. 
Cotton and Man-Made Fiber Underwear (United States - Underwear), which stated:

Article $\mathrm{X}: 2$. . may be seen to embody a principle of fundamental importance-that of promoting full disclosure of governmental acts affecting Members and private persons and enterprises, whether of domestic or foreign nationality. The relevant policy principle is widely known as the principle of transparency and has obviously due process dimensions. The essential implication is that Members and other persons affected, or likely to be affected, by governmental measures imposing restraints, requirements, and other burdens, should have a reasonable opportunity to acquire authentic information about such measures and accordingly to protect and adjust their activities or alternatively to seek modification of such measures ...65

The Appellate Body's identification of the fundamental importance of Article $\mathrm{X}$ lies in sharp contrast to earlier panel discussions of Article X under GATT 1947. The reference to transparency and due process values enshrined in the text of Article X have been widely quoted by subsequent WTO panels. Of particular significance is the Appellate Body's view that Article X's transparency and due process protections extend to administrative actions taken by Members in relation to their own citizens (i.e. internal governance, as well as in relation to foreign traders). Another point highlighted by the Appellate Body in United States - Underwear is that Article X, unlike other GATT provisions, is explicitly concerned with the rights and expectations of traders. Finally, the Appellate Body clarified that Article $\mathrm{X}$ allows challenges to the administration of measures that are otherwise WTO consistent.

The importance of Article X was also underscored by the Appellate Body in United States - Import Prohibition of Certain Shrimp and Shrimp Products (US - Shrimp). ${ }^{66}$ In that case, the Appellate Body held that a US measure prohibiting importation of shrimp or shrimp products fell within the scope of Article XX(g) of the GATT 1994 as a measure that was aimed primarily at the conservation of an exhaustible natural resource, giving effect to restrictions on domestic production or consumption. ${ }^{67}$ But the US conservation measure failed the requirements of the chapeau of Article XX because the United States applied the measure in a manner that constituted arbitrary and unjustifiable discrimination between countries where the same conditions prevail. ${ }^{68}$ The Appellate Body went on to state:

Provisions of Article X:3 of the GATT 1994 bear upon this matter. In our view Section 609 [the United States restriction on shrimp imports] fall within the [scope of] Article X:1. Inasmuch as there are due process

\footnotetext{
${ }^{65}$ Appellate Body Report, US - Underwear, above n 60, at 20 (emphasis added).

${ }^{66}$ Appellate Body Report, US - Shrimp, above n 60.

${ }^{67}$ Ibid, para 113.

${ }^{68}$ Ibid, para 177.
} 
requirements generally for measures that are otherwise imposed in compliance with WTO obligations, it is only reasonable that rigorous compliance with the fundamental requirements of due process should be required in the application and administration of a measure which purports to be an exception to the treaty obligations ...69

The Appellate body in US-Shrimp also goes on to state that the US measure at issue, Section 609, was applied in a manner that was "contrary to the spirit, if not the letter, of Article X:3 [of GATT 1994]".70

\section{A. The scope of measures covered under Article X:1 of the GATT 1994}

Article X requires that 'laws, regulations, judicial decisions and administrative rulings of general application' (collectively 'measures') be promptly published and administered 'uniformly, impartially and reasonably. ${ }^{71}$ Panels and the Appellate Body, on the whole, have given the term 'general application' a generous interpretation so as not to limit the scope of measures covered under Article X:1. In European Communities - Regime for the Importation, Sale and Distribution of Bananas (EC - Bananas III), ${ }^{72}$ the panel and the Appellate Body stated that Article X applies to both internal measures and border measures. ${ }^{73}$ In Fapan - Measures Affecting Consumer Photographic Film and Paper (Fapan - Film), the panel held that a measure qualifies under Article X:1 as an administrative ruling of general application even if it is addressed to only a specific company or shipment if such a ruling establishes or revises principles applicable in future cases. ${ }^{74}$ This reasoning was followed in Argentina - Hides and Leather, ${ }^{75}$ in which the panel held that a resolution that permitted representatives of the domestic tanning industry to be present during the customs process of export clearance was an administrative measure of general application under Article X:1 even if only one company benefited from it. ${ }^{76}$

In anti-dumping cases, however, panels have been reluctant to find specific dumping determinations 'measures of general application'. In United States Anti-Dumping Measures on Certain Hot-Rolled Steel Products from fapan (United States - Hot-Rolled Steel), ${ }^{77}$ the panel held that a specific antidumping ruling in a particular case did not qualify as a measure of general application. Nevertheless, the panel did state that in certain circumstances,

${ }^{69}$ Appellate Body Report, US - Shrimp, above n 60, para 182.

${ }^{70}$ Ibid, para 183.

${ }^{71}$ Articles X:1 and X:3(a) of the GATT 1994, see WTO, above n 1.

72 Appellate Body Report, EC - Bananas III, above n 60; Panel Report, EC - Bananas III, above n 60.

${ }^{73}$ Panel Report, EC - Bananas III (Mexico), above n 60, para 7.206; Appellate Body Report, EC - Bananas III, above n 63, para 70. Interestingly, the EC responded that Art. X 'only applies to internal measures and therefore not applicable in this case' at para 33).

${ }^{74}$ Panel Report, Japan - Film, above n 60, paras 10.384-10.388.

${ }^{75}$ Panel Report, Argentina - Hides and Leather, above n 60.

${ }^{76}$ Ibid, para 10.5.

${ }^{77}$ Panel Report, US - Hot-Rolled Steel, above n 60. 
the outcome of a single antidumping investigation could have 'significant impact on the overall administration of the law' and therefore could be considered a measure of general application within the scope of Article $\mathrm{X}: 1{ }^{78}$ In 2004, in Dominican Republic - Import and Sale of Cigarettes, the panel decided that a survey taken by the Dominican Republic's Central Bank on average prices of cigarettes was an 'administrative ruling of general application' and should have been published because it was 'an essential element of an administrative ruling' within the scope of Article X:1. ${ }^{79}$

In sum, panels and the Appellate Body have adopted an expansive interpretation of the term 'measures of general application', which includes any specific act of administration that has a 'significant impact' on the overall administration of the law or any government action, including a survey, which subsequently forms a basis for an administrative ruling. At the same time, however, panels and the Appellate Body have retained the flexibility to exclude a measure from the scope of Article X:1 if they determine that it does not have a significant impact on the overall administration of a measure.

\section{B. The scope of Article X:3 of the GATT 1994}

Article X:3(a) requires WTO Members to 'administer in a uniform, impartial and reasonable manner all its laws, regulations... and administrative rulings of the kind referred to in Article X:1' Article X:3(b) and (c) require independent or 'objective and impartial review' of all administrative actions that relate to customs matters.

WTO panels and the Appellate Body have interpreted the term 'applied uniformly' to mean that 'customs laws should not vary, that every exporter and importer should be able to expect treatment of the same kind, in the same manner over time and in different places and with respect to the other persons. ${ }^{80}$ Panels have also stated that 'access to' and 'flow of information' are essential to meeting the due process requirements of Article X:3(a). The panel in Argentina - Hides and Leather stated that 'the requirement of reasonableness and impartiality... both relate to the question of information' and that unless 'access to information' is uniform and reasonable the administration of a measure cannot be impartial. ${ }^{81}$ Panels have also emphasized that the three requirements of Article X:3(a) are not cumulative, and that a measure must satisfy all three requirements separately. ${ }^{82}$ In Argentina Hides and Leather, the panel pointed out that Article X:3(a) applies to the substance of an administrative measure. ${ }^{83}$ Panels have also held that the

\footnotetext{
78 Ibid, para 7.268.

79 Panel Report, Dominican Republic - Import and Sale of Cigarettes, above n 60, paras 7.405-406.

${ }^{80}$ Panel Report, Argentina - Hides and Leather, above n 60, para 11.83.

81 Ibid, para 11.86.

82 Panel Report, Dominican Republic - Import and Sale of Cigarettes, above n 60, para 7.383.

83 Panel Report, Argentina - Hides and Leather, above n 60, para 11.71.
} 
scope of Article X:3(a) is not limited by the most-favored-nation (MFN) requirement. There is no requirement that Article X:3(a) be applied only in situations where the measure has been applied in an inconsistent manner with respect to the imports from or exports to two or more Members. ${ }^{84}$

There has been great reluctance in applying the provisions of Article $\mathrm{X}: 3$ (a) to specific anti-dumping actions. In United States - Anti-Dumping Duty on Dynamic Random Access Memory Semiconductors (DRAMS) of One Megabit or Above from Korea (US - DRAMS), Korea argued that the due process values of Article X:3(a) renders every action taken by the DOC in administering anti-dumping measures susceptible to scrutiny. ${ }^{85}$ Similarly, in United States - Hot-Rolled Steel, Japan argued that the scope of Article X:3(a) was broader than the covered agreements because the standards contained in Article X:3 represent in one sense the notion of good faith and in another sense the 'fundamental requirements of due process,' and that these principles should be applied to the manner in which the DOC administered the anti-dumping laws. ${ }^{86}$

In Dominican Republic - Import and Sales of Cigarettes, the panel defined the term 'reasonable' as 'in accordance with reason, not irrational or absurd, proportionate. ${ }^{87}$ The panel ruled that the administration of the provisions of the Selective Consumption Tax was 'unreasonable' and in violation of Article X:3(a) because it used the 'nearest similar product' to determine the tax rate on imported cigarettes while that was not the criteria that had been stated in the regulation. The Dominican Republic acknowledged the problem with using the nearest similar product and removed the measure while the case was before the panel. Nevertheless, the panel engaged in a relatively extensive discussion of the meaning of the term 'reasonable' in Article X:3(a) and ruled that the Selective Consumption Tax, as it was administered prior to the change, was unreasonable.

\section{Protecting the expectations of traders}

A distinguishing feature of WTO-era Article X jurisprudence has been that the panels have looked towards the expectations of private individual traders who operate in the market place. For example, in United States - Sunset Reviezws of Anti-Dumping Measures on Oil Country Tubular Goods from Argentina (US - Oil Country Tubular Goods Sunset Reviews) the panel concentrated on showing the 'real effect' of the DOC's sunset reviews on 'foreign traders operating in the commercial world'. ${ }^{88}$ This is unique within the context of the GATT and the WTO where emphasis has been

\footnotetext{
${ }^{84}$ Ibid, para 11.67.

85 Panel Report, US - DRAMS, above n 60.

${ }^{86}$ Panel Report, US - Hot-Rolled Steel, above n 60, para 7.263.

87 Panel Report, Dominican Republic - Import and Sale of Cigarettes, above n 60, para 7.385.

88 Panel Report, US - Oil Country Tubular Goods Sunset Reviews, above n 60, para 202-210.
} 
on 'expectations of a competitive relationship' between the Members based on a system of reciprocity and mutual concessions.

In Argentina - Hides and Leather, the panel addressed the issue of the expectation of traders as follows:

Article X:3(a) requires an examination of the real effect that a measure might have on traders operating in a commercial world. This, of course, does not require a showing of trade damage, as that is not generally a requirement with respect to violations of GATT 1994. But it can involve an examination of whether there is possible impact on the competitive situation due to alleged partiality, unreasonableness or lack of uniformity in application of custom rules ... ${ }^{89}$

The direct and explicit reference to 'expectations of traders' is significant in at least two respects. First, it emphasizes the importance of Article $\mathrm{X}$ as private traders ask their governments to focus on the lack of transparency and uniformity in the application of internal or border measures. Second, it underscores the good governance mandate of the WTO as an organization that is expected to protect the expectations of private actors (not only governments) by safeguarding transparency, accountability and other due process values. This, in turn, demonstrates the evolution of the system away from one based on reciprocal bargaining and mutual concessions among Members to a system that promotes rules of good governance.

\section{Relationship of Article X of GATT 1994 and the WTO agreement}

There is a great deal of uncertainty regarding the relationship between the provisions of GATT 1994, including Article X, and other Annex 1A agreements. The Interpretative Note to Annex $1 \mathrm{~A}$ does not solve this problem as it only provides that, in cases of 'conflict' between the GATT 1994 and other Annex 1A agreements, the provision of the other agreement prevails but only to the 'extent of the conflict.' 90 What does 'conflict' mean when dealing with Article X's relationship to another agreement? As might be expected, the answer to this question is not clear and seems to vary depending on the other agreement at issue.

In United States - Underwear, Costa Rica argued that the United States' safeguard action against imports of cotton and manmade fiber underwear was inconsistent with both the Agreement on Textiles and Clothing (ATC) ${ }^{91}$ and Article X:2 of the GATT $1994 .{ }^{92}$ The panel held that a transitional safeguard measure was subject to the publication requirements of Article $\mathrm{X}: 2$ as well as the ATC. On appeal, the Appellate Body overturned the

\footnotetext{
${ }^{89}$ Panel Report, Argentina - Hides and Leather, above n 60, para 11.77.

${ }^{90}$ WTO, above $\mathrm{n} 1$, at 16 .

${ }^{91}$ Ibid, at 73.

92 Panel Report, United States - Underwear, above n 60.
} 
Article $\mathrm{X}: 2$ violation, but on the ground that Article $\mathrm{X}: 2$ does not address whether or not a Member can give retroactive effect to a safeguard measure. While it did not expressly address the relationship between the provisions of the GATT 1994 and the text of other agreements, the Appellate Body in United States - Underwear did clearly imply that both can apply. ${ }^{93}$

The relationship between Licensing Agreement and Article $\mathrm{X}$ was addressed in EC - Bananas III, in which the panel interpreted the term 'conflict' in the Interpretative Note narrowly to include only those instances where a provision in one agreement prohibits what another agreement explicitly permits or where a Member cannot comply with both the requirements of another Annex 1A agreement and Article X. ${ }^{94}$ The Appellate Body agreed with the panel that the Interpretative Note allows for the application of both Article X:3 and the Licensing Agreement, but ruled that the panel should have applied the Licensing Agreement first, as it was the more specific and detailed agreement. ${ }^{95}$ If the panel had applied the Licensing Agreement first, the Appellate Body reasoned, 'then there would be no need for it to address ...Article X:3(a) of GATT 1994. ${ }^{96}$

This GATT 1947-like approach of ignoring the requirements of Article $\mathrm{X}: 3$ was challenged in European Communities - Measures Affecting Importation of Certain Poultry Products (EC - Poultry). ${ }^{97}$ The panel in EC - Poultry found that, unlike the EC - Bananas III case, even after reviewing the Licensing Agreement, it was obliged to look at Article X:3(a). The panel reasoned that this was appropriate because the Licensing Agreement was only relevant to a portion of the measure at issue, while the scope of Article $\mathrm{X}$ was broader. ${ }^{98}$

In contrast to the Licensing Agreement, panels have been reluctant to apply Article X:3(a) to measures falling within the scope of the Antidumping Agreement. In United States - Hot-Rolled Steel the panel stated:

Where we have found a particular action or category of action is not inconsistent with a specific provision of the $\mathrm{AD}$ Agreement, we are

93 Appellate Body Report, United States - Underwear, above n 60 (specifically concluding that Art. X:2 does not address the issue of whether or not a member can give retroactive effect to a safeguard measure).

94 Panel Report, EC - Bananas III (Mexico), above n 60, para 7.159.

95 Appellate Body Report, EC - Bananas III, above n 60, para 204.

${ }^{96}$ Ibid.

97 Panel Report, EC - Poultry, above n 60. In EC - Poultry, Brazil had argued that the European Communities' rules relating to imports of frozen poultry were applied in violation of Art. X since Brazilian traders cannot know whether a particular shipment is subject to in or out of quota rules (at para 267). The Appellate Body ruled that 'Article X...does not impose an obligation on Member governments to ensure that exporters are continuously notified by importers are to the treatment of particular impending shipments.' See Appellate Body Report, EC - Poultry, above n 60, para 114.

98 The panel held that 'the examination of Article $\mathrm{X}$ as well as the [Licensing Agreement] is warranted since...the [Licensing Agreement] is relevant to only in quota trade and Article $\mathrm{X}$ to the total trade'. See Panel Report, EC - Poultry, ibid, para 268. 
faced with the question whether a Member can be found to have violated Article $\mathrm{X}: 3$ (a) ... we have serious doubts as to whether such a finding would be appropriate. ${ }^{99}$

While this statement does not make Article X:3 explicitly inapplicable to the Antidumping Agreement, it is clear the panel did not find it is appropriate to apply the due process provisions of Article X:3 to the administration of antidumping measures in addition to the due process requirements of the Antidumping Agreement. The applicability of the terms of Article X:3(a) to the administration of US anti-dumping laws was argued forcefully by Korea in US - DRAMS:

WTO Agreements are a unitary whole. The transparency and uniformity obligations of Article X apply to the WTO Agreements, including the [Anti-Dumping Agreement] ... the Member must administer each statute, regulation, and administrative ruling in a way that complies with Article $\mathrm{X}: 3$. Thus Article $\mathrm{X}$ applies to each and every action of the [DOC] ${ }^{100}$

In response, the panel was reluctant to apply Article X:3(a) to the DOC's actions:

... we have grave doubts as to whether Article X:3(a) can or should be used in the manner advocated by Korea. As the United States correctly points out... [Article $\mathrm{X}: 3(\mathrm{a})$ ] was not intended to function as a mechanism to test the consistency of a Member's particular decision or rulings with the Member's own domestic law and practice; that is a function reserved for each Member's domestic judicial system $\ldots{ }^{101}$

The discomfort of panels in reviewing the administrative structure of a Member is understandable. However, that is what Article $\mathrm{X}: 3(\mathrm{a})$ allows by giving Members the right to challenge the administration of particular measures.

\section{THE EC - SELECTED CUSTOMS MATTERS DISPUTE}

Some sixty years after its inclusion in the GATT 1947, Article X was invoked as the sole legal basis for a trade dispute. In EC - Selected Customs Matters, ${ }^{102}$ the United States claimed that the EEC system of customs administration 'as a whole' was not administered uniformly as required by Article X:3(a). ${ }^{103}$ In its complaint, the United States also pointed to the

\footnotetext{
99 Panel Report, US - Hot-Rolled Steel, above n 60, para 7.267.

100 Panel Report, US - DRAMS, above n 60, para 4.461.

101 Panel Report, US - Stainless Steel, above n 60, para 6.50.

102 Panel Report, EC - Selected Customs Matters, above n 10.

103 The Appellate Body defined the crux of the United States position as: 'the European Communities administers its customs laws through 25 separate independent customs authorities and does not provide any institution or mechanism [at the community level] to reconcile the divergences automatically and as a matter of right when they occur'. See Appellate Body Report, EC - Selected Customs Matters, above n 10, para 22.
} 
specific non-uniform application of valuation rules and the administration of customs regulations to imports of liquid crystal display (LCD) monitors and blackout drapery. The United States argued that the lack of any mechanism at the EEC level to address divergences in customs administrations was a violation of the uniformity requirement of Article X:3 (a). ${ }^{104}$

The panel agreed that the EC's system of custom administration as a whole is 'complicated and, at times, opaque and confusing. ${ }^{105}$ In fact, the panel further stated:

We can imagine that the difficulties we encountered in our efforts to understand the EC's system of customs administration would be multiplied for traders in general and small traders in particular who are trying to import into the European Communities. ${ }^{106}$

Nevertheless, the panels dismissed the 'as a whole' challenge as not within the panel's terms of reference. ${ }^{107}$ The panel did mention, however, that 'there is nothing in the DSU nor in other WTO agreements that would prevent a complaining Member from challenging a Member's system as a whole or overall. ${ }^{108}$ The panel did find violations of Article $\mathrm{X}: 3$ (a) due to non-uniform classification of LCD monitors and blackout drapery linings, and the non-uniform administration of valuation rules by EC members. ${ }^{109}$

On appeal, the Appellate Body held that the EC's system of customs administration could be challenged 'as a whole or overall' under Article $\mathrm{X}: 3$ (a) and that such a challenge was within the scope of the terms of reference. ${ }^{110}$ The Appellate Body went on to hold that the administrativesubstantive distinction maintained in EC - Bananas III and EC - Poultry did not exclude the possibility of allowing challenges to the substance of a measure that leads to inconsistent administration. Specifically, the Appellate Body stated that earlier rulings did 'not exclude... the possibility of challenging under Article X:3(a) the substantive content of a legal instrument that regulates the administration of a legal instrument of the kind described in

${ }^{104}$ The United States also claimed that violation of Art. X:3(b) based on the fact that decisions of administrative agencies and customs authorities in one member state does not govern the practice of EC agencies throughout the European Union. Ibid, at para 304.

105 Panel Report, EC-Selected Customs Matters, above n 10, para 7.191.

${ }^{106}$ Ibid.

107 Ibid, para 8.1

108 Ibid, para 7.44.

${ }^{109}$ Ibid [also holding in addition that there was no violation of Art. X:3(b)].

110 The Appellate Body stated that the panel was wrong in determining that the claim 'as a whole or overall' was outside the scope of the terms of reference of Art. X:3(a) and it could not be ruled on. See generally Appellate Body Report, EC - Selected Customs Matters, above n 10. 
Article X:1. ${ }^{111}$ Thus, a Member can challenge the substantive content of a legal instrument if such content determines the administration of that regulation, so long as it can be shown that the substantive measure necessarily leads to lack of uniform, impartial or reasonable administration in violation of Article X:3(a). ${ }^{112}$ The Appellate Body held that mere differences in customs laws among EC member states did not necessarily breach the uniformity requirement in Article X:3(a), unless such differences actually lead to non-uniform administration in specific cases. ${ }^{113}$

Having found that the EC system can, in principle, be challenged as a whole, under Article X:3(a), the Appellate Body sidestepped the 'as a whole' challenge by stating that the record does not provide the Appellate Body with enough facts to decide such a claim. Furthermore, the Appellate Body reversed two specific panel findings of inconsistency with Article X:3(a) relating to the administration of customs penalty laws and audit procedures and the tariff classification of blackout drapery, and upheld only the finding that the tariff classification of certain LCD monitors amounted to nonuniform administration in violation of Article X:3(a) and the panel's dismissal of the claim relating to Article $\mathrm{X}: 3(\mathrm{~b}) .{ }^{114}$ In this landmark case, by further blurring the administrative-substantive distinction, the Appellate Body sanctioned the wider use of Article $\mathrm{X}$ and opened the door for future claims including challenges to the substance of laws as a whole. ${ }^{115}$

\section{THE 'CULTURE' OF THE WTO DSM AND THE FUTURE OF ARTICLE X}

The evolution of the jurisprudence of the Article $\mathrm{X}$ under the WTO has expanded the scope of Article $\mathrm{X}$ through interpretations of its provisions and blurring the distinction relied on by earlier panels between a substantive and an administrative measure. The culture of the WTO DSM is such, however, that expansive interpretations of Article $\mathrm{X}$ are not necessarily accompanied by application of Article $\mathrm{X}$ requirements in specific cases.

111 Ibid, para 200.

112 Ibid, para 201.

113 Ibid, para 304.

114 Ibid.

115 This decision may have also expanded the scope of measures more generally by weakening further the mandatory/discretionary distinction which was first formulated under the GATT 1947 and was adhered to in varying degrees in the WTO. The mandatory/discretionary distinction states that only measures that 'mandate' WTO-inconsistent action should be challenged 'as such', and all discretionary measures that may or may not result in WTO inconsistent administration should be challenged 'as applied'. In EC - Selected Customs Matters, the Appellate Body held that member states can challenge the substance of measures regardless of the mandatory or discretionary substance of the measure. A fuller discussion of this distinction is beyond the scope of this article. For further discussion of mandatory/ discretionary distinction, see e.g. WTO Appellate Body Report, United States-Anti-dumping Act of 1916, WT/DS136/R, WT/DS136/AB/R, Adopted on 26 September 2000; WTO Panel Report, United States-Section 301-310 of the Trade Act of 1974, WT/DS152/R, Adopted on 27 January 2000. 
It is also unclear the extent to which due process requirements of Article $\mathrm{X}: 3$ (a) are applicable to measures that fall within the scope of various Annex $1 \mathrm{~A}$ agreements.

Article X:3(a) requirements have not been applied to the Antidumping Agreement, but they have been found to be concurrently applicable with the due process requirements of the Licensing Agreement. Some Members of the WTO view the administration of US trade remedy laws (specifically in the anti-dumping context) to be inconsistent with Article X:3(a) requirements of uniformity, impartiality and reasonableness. ${ }^{116}$ It is, therefore, likely that Article $\mathrm{X}$ will continue to be asserted against the United States, the original architect of Article $\mathrm{X}$, as Members emphasize values of fundamental due process, such as transparency and access to information. Panels and the Appellate Body are unlikely to apply Article X to the administration of US trade remedy laws. Instead, panels will likely continue to focus on the specific procedural provisions of the Antidumping Agreement, SCM Agreement, and the Agreement on Safeguards.

Such an approach is consistent with the culture of the DSU. For example, in EC - Selected Customs Matters, the Appellate Body expanded the scope of measures that can be challenged under Article X:3(a), but at the same time largely reversed the panel's finding of inconsistency with Article X:3(a) and only affirmed the panel's finding that the non-uniform administration of the tariff classification of LCD monitors by EU members was a violation of Article X:3(a). Similarly, in Dominican Republic - Import and Sale of Cigarettes, there is an extensive discussion of the meaning of the term 'reasonable' in Article X:3, even though the measures at issue had already been withdrawn. In $U S-D R A M S$, the panel addressed Article X:3 only to conclude that the inconsistency of the measure with the Antidumping Agreement rendered examination of Korea's claims under Article X unnecessary. The seeming discrepancy between the relatively extensive discussions of the requirements of Article X:3(a), and the refusal of the panels to rule on Article $\mathrm{X}$ claims is consistent with the culture and practices of the DSM. The practice under the DSU is to avoid making controversial decisions, while incrementally developing the jurisprudence so that future panels and the Appellate Body can accommodate the expansion of the WTO mandate into areas that go beyond the traditional sphere of securing or promoting

116 Most recently, in 2008 India brought an action against the imposition of anti-dumping duties by United States on imports of shrimp from India, claiming a violation of Art. X:3 in addition to the Anti-Dumping Agreement, and Arts XI, XIII, and II of the GATT 1994. The panel, however, on the basis of judicial economy, did not address any of the GATT 1994 claims after having found the measures inconsistent with the Anti-Dumping Agreement. It is noteworthy, that India attempted to make both 'as applied' and 'as such' claims under Art. X:3(a) with the latter being rejected by the panel for being untimely. See Appellate Body Report, US - Customs Bond Directive, above n 60. 
trade liberalization, and into promoting good governance within Members. ${ }^{117}$

Recent interpretations of the scope of Articles X:1 and X:3(a) have expanded the scope of those provisions. The ruling in EC - Selected Customs Matters, that a system as a whole can be challenged under Article $\mathrm{X}: 3$ (a), will likely encourage Members to bring additional complaints. Specifically, Article X challenges to the EC's system of customs administration are likely to continue given the view expressed by the panel that the EC customs regulations can be opaque and confusing. In addition, United States - Shrimp has made the jurisprudence of Article X applicable 'in spirit' if not 'in letter' to the chapeau of Article XX. It is therefore possible that the developing jurisprudence of Article X, and specifically of Article X:3(a), may be used to interpret the application of Article XX measures or to otherwise guide the interpretation of the chapeau of Article XX.

\section{CONCLUSION}

Article X of the GATT 1994 is the oldest good governance provision of the WTO Agreements. A close study of its history and evolving jurisprudence contributes to an understanding of the emerging role of the WTO as a potential supra-national regulatory body and the final arbiter of appropriate administrative and regulatory structures. ${ }^{118}$ The broad language of Article $\mathrm{X}$ allows the WTO to review domestic administrative legal regimes based on interpretation of the terms: uniform, impartial, and reasonable. Applying those standards to administrative acts and practices of WTO Members, particularly in the context of claims against administrative systems as a whole, could raise serious concerns if seen as interfering in the internal governance of Members. Although such increased reference to fundamental values of transparency and due process may be a sign of an emerging consensus on the elements for good governance, it also has the potential to undermine the utility of such values if they are not addressed or applied in an even-handed manner by panels and the Appellate Body.

117 See Debra P. Steger, 'The Culture of the WTO: Why It Needs to Change', 10 Journal of International Economic Law 483 (2007), at 485-86. As Professor Steger writes: 'The mandate and purpose of the WTO is no longer clear. The mandate of the GATT system was continuing the process of trade liberalization...the preamble to the GATT 1947 reflected these goals. The preamble of the WTO Agreement is broader - it includes the goals of environmental sustainability and development...but they have not become part of the accepted theology or culture of the WTO as perceived by its members. So, there is a difference between what the preamble of the WTO says the purpose of the organization is and what its members perceive it to be.'

118 The work of the TPRM and committees in the area of good governance as expressed in Art. $\mathrm{X}$ must also be studied to get a fuller picture of the good governance mandate of the WTO. Such work is necessary to assist the DSU in its application of Art. X. 
The WTO is no longer a system simply based on consensus, reciprocity, and a balancing of concessions. Rather, it is a system based on rules that reflect the reality of the administrative state. The goal of the multilateral trading system is no longer free trade (if it ever was) but rather trade that is regulated in a WTO-consistent manner. As a result, the good governance provisions of the WTO, those addressing transparency and due process, are increasingly central to WTO disputes. Fortunately, the multilateral trading system is very adept at making incremental change. To date, the Appellate Body and panels have been, in most cases, reluctant to find a measure inconsistent with the obligations of Article X:3(a), but have continued to build the jurisprudence of Article X:3(a) through interpretation of its provisions and applauding the values it enshrines. ${ }^{119}$

There is much at stake in how the DSM addresses future transparency claims. There is great discrepancy among Members in terms of their administrative structures and institutional capacity and the DSM may not be the most appropriate forum to address such differences. It is possible that countries with advanced and complicated regulatory structures may feel more vulnerable to charges of inconsistency with transparency and due process obligations of the WTO. It is therefore important that the WTO acknowledge its good governance mandate through coordination between the transparency related works of its various committees and the TPRM's mandate to monitor domestic transparency in trade decision-making area. This coordination could also assist the DSM in interpreting and applying the transparency related obligations of the WTO Agreements.

119 Another example of incremental change has been Art. XX of the GATT 1994, where the Appellate Body discussed at great length the need to justify environmental measures under Art. XX and elaborated on how Art. XX should be read and applied years before they actually found a measure justified under Art. XX. In 1999, in the aftermath, of United States - Shrimp, I wrote: 'the Appellate Body's analysis of Article XX generally and subparagraph (g) in particular...indicates that although supporters of Article XX interests [environmentalists] may have lost the battle, the prospects look good for winning the war'. See Padideh Ala'i, 'Free Trade or Sustainable Development? An Analysis of the WTO Appellate Body's Shift to a More Balanced Approach to Trade Liberalization', 14 American University International Law Review 1129 (1998), at 1170-71 